\title{
PEMANFAATAN JAMUR METHARIZIUM ANISOPLIAE BERASAL DARI ISOLAT BRONTISPA LONGISSIMA MENGENDALIKAN LARVA (ORYCTES RHINOCEROS) SECARA INVITRO
}

\author{
Lita Nasution ${ }^{1}$, Abdul Rahman Cemda ${ }^{2}$, Soni Isnaini ${ }^{3}$, Muhammad Afrillah ${ }^{4}$, Pindi Filsa ${ }^{5}$ \\ ${ }^{1}$ Dosen Agroteknologi, Fakultas Pertanian, UMSU, Medan, Indonesia. \\ ${ }^{2}$ Dosen Agribisnis, Fakultas Pertanian, UMSU, Medan, Indonesia. \\ ${ }^{3}$ Dosen STIPER Dharma Wacana Metro, Kota Metro, Bandar Lampung, Indonesia. \\ ${ }^{4}$ Dosen Agroteknologi, Fakultas Pertanian, Universitas Teuku Umar, Aceh Barat Meulaboh, Indonesia \\ ${ }^{5}$ Alumni Agroteknologi, Fakultas Pertanian, Universitas Al-Azhar, Medan, Indonesia.
}

Koresponden Email: litanasution@umsu.ac.id

\begin{abstract}
Abstrak
Penelitian ini bertujuan untuk mengetahui virulensi jamur entomopatogen Metharizium anisopliae isolat Brontispa longissima dengan konsentrasi yang berbeda untuk mengendalikan larva hama kumbang tanduk $O$. rhinoceros pada tanaman kelapa sawit. Penelitian ini dilaksanakan di Laboratorium Penyakit Tanaman, Fakultas Pertanian, USU pada Oktober 2020. Penelitian ini menggunakan Rancangan Acak Lengkap (RAL) Non Faktorial yang terdiri dari 4 perlakuan dengan 5 ulangan. Adapun perlakuannya sebagai berikut : $\mathrm{M}_{0}$ (Tanpa pemberian jamur), $\mathrm{M}_{1}$ (Jamur $M$. anisopliae dengan konsentrasi $20 \mathrm{gr}$ x $100^{-1} \mathrm{ml}$ aqua pro injection), $\mathrm{M}_{2}$ (Jamur $M$. anisopliae dengan konsentrasi $40 \mathrm{gr} \times 100^{-1} \mathrm{ml}$ aqua pro injection), $\mathrm{M}_{3}$ (Jamur M. anisopliae dengan konsentrasi 60 gr x $100^{-1} \mathrm{ml}$ aqua pro injection.). Parameter yang diamati meliputi persentase mortalitas larva kumbang tanduk $O$. rhinoceros, jumlah kerapatan konidia $M$. anisopliae, gejala kematian larva $O$. rhinocerossecara visual, dan waktu kematian larva $O$. rhinoceros. Hasil analisis sidik ragam menunjukkan bahwa persentase mortalitas larva hama $O$. rhinoceros terhadap perlakuan berbeda tidak nyata pada 1-5 Hari Setelah Aplikasi (HSA), berbeda nyata pada 6 Hari Setelah Aplikasi (HSA) dan berbeda sangat nyata pada 7-14 Hari Setelah Aplikasi (HSA). Persentase mortalitas larva Oryctes rhinoceros tertinggi terdapat pada perlakuan $\mathrm{M}_{1}, \mathrm{M}_{2}$ dan $\mathrm{M}_{3}$ sebesar $100 \%$ terlihat pada hari ke-13 dan ke-14 sedangkan persentase mortalitas terendah terdapat pada perlakuan $\mathrm{M}_{0}$ yaitu $24 \%$, jumlah kerapatan konidia tertinggi terlihat pada jamur $M$. anisopliae dengan konsentrasi 60 gr x $100^{-1} \mathrm{ml}$ aqua pro injection dengan pengenceran $10^{2}$ dengan kerapatan konidia sebanyak $6,05 \times 10^{8}$. Gejala kematian larva $O$. rhinoceros yang terinfeksi jamur $M$. anisopliae yaitu larva mengeras dan akan muncul koloni jamur berwarna hijau tua disekitar tubuh larva dan waktu yang dibutuhkan jamur $M$. anisopliae untuk menyebabkan kematian awal adalah 2 hari setelah aplikasi (HSA) yaitu pada perlakuan $\mathrm{M}_{2}$ dan $\mathrm{M}_{3}$. Setelah itu kematian 4 hari setelah aplikasi (HSA) pada perlakuan $\mathrm{M}_{1}$. Kedua Jamur Fusarium $s p$ dan Trichophyton $s p$ efektif dimanfaatkan sebagai pengendali serangan larva $O$. rhinoceros skala laboratorium/invitro.
\end{abstract}

\section{Kata Kunci : Jamur Metharizium Anisopliae, Asal Isolat Brontispa Longissima, Larva Oryctes Rhinoceros, $\boldsymbol{h}$-vitro}

\begin{abstract}
This study aimed to determine the virulence of entomopathogenic fungus M. anisopliae using Brontispa longissima isolates with different concentrations to control larvae of the horn beetle O. Rhinoceros by invitro. This research was conducted at the Plant Disease Laboratory, Faculty of Agriculture, USU in October 2020. This study used a non-factorial completely randomized design (CRD) consisting of four treatments with five replications. The treatments were as follows: M0 (without M. anisopliae mushroom), $M_{1}$ (M. anisopliae mushroom with a concentration of $20 \mathrm{gr} \times 100^{-1} \mathrm{ml}$ aqua pro injection), $M_{2}$ (M. anisopliae mushroom with a concentration of $40 \mathrm{gr}$ $x 100^{-1} \mathrm{ml}$ aqua pro injection). The result of analysis of variance showed that the mortality percentage of $O$. rhinoceros was not significantly different at 1-5 Days After Application (HSA), significantly different at 6 Days After Application (HSA) and very significantly different at 7-14 Days After Application. (HSA). The highest mortality percentage of $O$. rhinoceros larvae was found in the $M 1, M_{2}$ and $M_{3}$ treatments on the $13^{\text {th }}$ and $14^{\text {th }}$ days while the lowest mortality percentage was found in the $M_{0}$ treatment, which was $24 \%$, the highest conidia density was seen in the fungus $M$. anisopliae with concentration of $60 \mathrm{gr} \times 100^{-1} \mathrm{ml}$ aqua pro injection with a dilution of $10^{2}$ with a conidia density of $6.05 \times 10^{8}$. Symptoms of the death from O. rhinoceros larvae which infected with M. anisopliae fungus are hardened larvae and have dark green fungal colonies will appear around the body larvae, and time required for M. anisopliae fungus to cause early death was 2 days after application (HSA) in $\mathrm{M}_{2}$
\end{abstract}

DOI: $\underline{\text { https://doi.org/10.55127/ae.v15i2.101 }}$ 
and $M_{3}$ treatments. After that death 4 days after application (HSA) in the M1 treatment. Both Fusarium sp and Trichophyton sp fungi were effectively used to control the larval attack of $O$. rhinoceros in laboratory/in vitro scale.

Keywords: Entomopathogenous fungus Fusarium sp, Trichophyton sp, Oryctes rhinoceros larvae, by in-vitro

\section{PENDAHULUAN}

Pertanian merupakan salah satu sektor utama dalam perekonomian masyarakat Indonesia. Kelapa sawit (Elaeis guineensis) sebagai tanaman dengan produk utama minyak sawit/ Crude Palm Oil (CPO). Tanaman kelapa sawit menduduki posisi penting di sektor pertanian umumnya, dan sektor perkebunan khususnya, karena menghasilkan nilai ekonomi terbesar per hektarnya di dunia [1].

Salah satu permasalahan dalam budidaya tanaman kelapa sawit adalah serangan hama yang dapat merusak tanaman sehingga produksi menurun. Hama dapat menyerang kelapa sawit sejak tanaman belum menghasilkan (TBM) hingga tanaman menghasilkan (TM) [2]. Kumbang tanduk (Oryctes rhinoceros) merupakan hama penggerek pucuk kelapa sawit yang menjadi hama utama tanaman kelapa sawit yang mengakibatkan rusaknya titik tumbuh, sehingga mematikan tanaman dan produksi tandan buah segar mengalami penurunan produksi [3].

Serangan kumbang tanduk terjadi karena tersedianya bahan makanan bagi kumbang tanduk, yaitu bahan organik yang terdapat di lahan perkebunan seperti pengaplikasian mulsa tandan kosong kelapa sawit yang berlebihan pada tanaman menghasilkan (TM) dan sisa tanaman replanting merupakan bahan organik yang disukai oleh kumbang tanduk [4].

Upaya pengendalian kumbang tanduk telah banyak dilakukan untuk menekan populasi hama menggunakan cara mekanik, kimiawi maupun pengendalian hayati, namun demikian belum berhasil menekan populasi [5]. Pengendalian kumbang tanduk sebagian besar dilakukan menggunakan insektisida kimia sintetik yang dianggap sebagai pengendalian utama karena dapat mengendalikan hama secara cepat dan praktis. Namun penggunaan insektisida kimia sintetik dapat menimbulkan dampak negatif seperti meracuni organisme non target, resistensi, dan resurjensi hama [3]. Penggunaan insektisida memiliki dampak negatif terhadap lingkungan karena mengandung residu insektisida Dichloro Diphenyl Trichloroethane (DDT) yang akan meningkatkan bahaya akumulasi residu kimia sintetik pada lahan dan hasil produksi tanaman sehingga dapat meningkatkan resiko kerusakan lingkungan [6].

Pemanfaatan agens hayati seperti virus, cendawan, bakteri, nematoda dan protozoa sebagai bioinsektisida mempunyai prospek yang baik dalam menggendalikan populasi hama tanaman karena memiliki patogenisitas yang tinggi terhadap hama sasaran, selain itu dapat digunakan dalam jangka waktu yang panjang, relatif murah dan ramah lingkungan [7]. Metarhizium anisopliae merupakan salah satu cendawan patogen pada serangga karena potensi sebagai pengendali alami untuk mengendalikan hama serangga pada berbagai komoditi tanaman. Karakteristik serangan jamur entomopatogen dapat mempengaruhi pertumbuhan larva kumbang tanduk di perkebunan kelapa sawit [8]. Hasil penelitian menunjukkan bahwa jamur $M$. anisopliae (diaplikasikan jamur $M$. anisopliae pada 20 gr media jagung) dapa mematikan larva kumbang tanduk sebesar $100 \%$ [9]. Berdasarkan uraian diatas, tujuan penelitian adalah untuk mengkaji pengaruh konsentrasi Metarhizium anisopliae yang diisolasi dari Brontispa longissima terhadap mortalitas dan waktu kematian larva kumbang tanduk instar III yang berasal dari tanaman kelapa sawit secara in vitro.

\section{METODE PENELITIAN Tempat dan Waktu Penelitian}

Penelitian telah dilaksanakan di Laboratorium Penyakit Tanaman, Fakultas Pertanian Universitas Sumatera Utara (FP USU) pada Bulan Oktober 2020.

\section{Bahan dan Alat}

Bahan-bahan yang digunakan dalam penelitian ini adalah larva hama kumbang tanduk yang berasal dari PT. Perkebunan Nusantara III (Persero) kebun Tanah Raja, jamur Metarhizium anisopliae yang diisolasi dari Brontispa longissima pada pertanaman kelapa di kecamatan Percut Sei Tuan kabupaten Deli Serdang, aqua pro injection, beras, Potato Dextrose Agar (PDA), dan alkohol 96\%. 
Alat yang digunakan dalam penelitian ini adalah cawan petri pyrex, tabung reaksi pyrex, rak tabung reaksi pyrex, bunsen pyrex, laminar air flow (LAF), thermo scientific 1300 series $\mathrm{B} 2$, plastik putih tahan panas mahkota obor, timbangan elektrik gf-400, mikroskop zeiss primo star, perangkat digital mikroskop optilab, object glass one lab 7101, haemocytometer nesco, shaker denley reciprocal mixer, autoclave tomy sx-700, hand sprayer ideal SIL-001 kapasitas 1 liter, test tube, stoples, kain kassa, karet gelang, label nama, sarung tangan, masker, cling wrap klin pak, alumunium foil klin pak, beaker glass pyrex, erlemeyer pyrex, gelas ukur pyrex, mikro pipet pyrex, jarum ose, kamera, dan alat tulis.

\section{Metode Penelitian}

Penelitian ini menggunakan Rancangan Acak Lengkap (RAL) Non Faktorial yang terdiri dari 4 perlakuan, yaitu:

$\mathrm{M}_{0}$ : Tanpa Pemberian Jamur

$\mathrm{M}_{1}$ : Jamur Metarhizium anisopliae dengan konsentrasi 20 gr x $100^{-1} \mathrm{ml}$ aqua pro injection aplikasi pada larva dan media.

$\mathrm{M}_{2}$ : Jamur Metarhizium. anisopliae dengan konsentrasi 40 gr x $100^{-1} \mathrm{ml}$ aqua pro injection aplikasi pada larva dan media.

$\mathrm{M}_{3}$ :Jamur Metarhizium. anisopliae dengan konsentrasi 60 gr x $100^{-1} \mathrm{ml}$ aqua pro injection aplikasi pada larva dan media.

Berdasarkan perlakuan yang dilakukan, maka jumlah ulangan dapat ditentukan dengan rumus sebagai berikut:

$t(r-1) \geq 15 \ldots$ Pers $(1)$

Dimana:

$\mathrm{t}=$ jumlah perlakuan

$r=$ jumlah ulangan

maka didapatkan $r=5$

Berdasarkan uraian diatas dapat disusun unit perlakuan sebagai berikut :

Jumlah Perlakuan : 4 perlakuan

Jumlah ulangan perlakuan : 5 ulangan

Jumlah unit penelitian : 20 unit

Jumlah larva per stoples $: 5$ ekor

Jumlah larva yang diuji : 100 ekor

Jarak antar stoples $\quad: 30 \mathrm{~cm}$

Jarak antar ulangan $\quad: 30 \mathrm{~cm}$

DOI: https://doi.org/10.55127/ae.v15i2.101
Jumlah stoples jamur Metarhizium anisopliae:

16 stoples

Jumlah stoples control $\quad: 4$ stoples

Jumlah stoples seluruhnya : 20 stoples

Model matematika yang digunakan pada penelitian ini adalah Rancangan Acak Lengkap Non Faktorial sebagai berikut:

$Y_{i j}=\mu+N_{i}++\varepsilon_{i j} \ldots$ Pers

dimana:

$\mathrm{Y}_{\mathrm{ij}} \quad$ : Hasil pengamatan dari perlakuan pemberian jamur M.anisopliae dengan metode aplikasi semprot pada larva dan media ke-i dan ulangan ke-j

$\mu \quad$ : Pengaruh nilai tengah

$N_{i} \quad$ : Pengaruh dari perlakuan pemberian jamur Metarhizium anisopliae pada taraf ke-i

$\sum_{i j}$ : Pengaruh galat dari perlakuan pemberian jamur Metarhizium anisopliae dengan metode semprot pada larva dan media kei dan ulangan ke-j

Terhadap faktor yang berpengaruh nyata dilakukan uji lanjut dengan menggunakan uji Duncan Multiple Range Test (DMRT) pada taraf $5 \%$ dan $1 \%$.

\section{Pelaksanaan Penelitian}

\section{Penyedian larva kumbang tanduk}

Larva kumbang tanduk dipelihara dalam stoples yang diberi tutup kain kassa dan diberi makan serasah pohon kelapa sawit. Larva dipelihara di Laboratorium Penyakit Tanaman FP USU. Larva dipelihara agar bertumbuh dengan baik. Kemudian diambil yang ukuran dan besarnya sama untuk dijadikan bahan pengujian. Larva yang akan diuji adalah larva instar III yang aktif dan sehat.

\section{Sterilisasi alat pendukung penelitian}

Alat yang digunakan terlebih dahulu disterilisasi dari patogen yang tidak diinginkan, dicuci bersih terlebih dahulu menggunakan alkohol 96\% dan Clorox 1\%. Kemudian dimasukkan dalam autoclave pada suhu $120^{\circ} \mathrm{C}$ dengan tekanan $1 \mathrm{~atm}$ selama 15 menit.

\section{Penyediaan jamur Metarhizium anisopliae}

Jamur yang digunakan dalam penelitian ini adalah Metarhizium anisopliae yang diisolasi dari Brontispa longissima yang berasal dari kebun kelapa miliki Balai Besar Perbenihan dan 
Proteksi Tanaman Perkebunan (BBPPTP) di kecamatan Percut Sei Tuan kabupaten Deli Serdang yang dalam bentuk biakan murni. Untuk mengantisipasi kekurangan dari jamur yang akan digunakan maka jamur diperbanyak dengan ditumbuhkan di media beras yang berisi $100 \mathrm{gr}$ per bungkus dan diinkubasi pada suhu ruang selama 30 hari. Pemindahan jamur ini dilakukan di dalam laminar air flow (LAF) untuk menghindari terjadinya kontaminasi. Jika terjadi kontaminasi, maka dilakukan pemurnian kembali dengan mengambil bagian jamur Metarhizium anisopliae yang tidak terkontaminasi untuk ditumbuhkan pada media beras sampai didapatkan jamur yang benar-benar murni dan tidak terkontaminasi.

\section{Persiapan media perlakuan}

Wadah yang digunakan adalah stoples dengan diameter $15 \mathrm{~cm}$ dan tinggi $15 \mathrm{~cm}$ sebagai tempat hidup larva selama penelitian. Dicuci bersih kemudian dikeringkan. Stoples diisi dengan makanan larva kumbang tanduk berupa serasah kelapa sawit yang diambil dari PT. Perkebunan Nusantara III kebun Tanah Raja dengan berat 200 gr per stoples. Media tersebut disediakan sebanyak 20 stoples. Kemudian larva kumbang tanduk dimasukkan ke dalam stoples masing-masing 5 ekor. Masing masing stoples kemudian ditutup dengan kain kasa dan diikat dengan karet gelang.

\section{Aplikasi jamur Metarhizium anisopliae}

Pengaplikasian dilakukan hanya sekali dengan cara menyemprotkan jamur entomopatogen Metarhizium anisopliae sesuai perlakuan pada larva kumbang tanduk dan media. Aplikasi jamur Metarhizium anisopliae menggunakan hand sprayer dengan $20 \mathrm{ml}$ per stoples bersaman dengan inokulasi larva. Aplikasi pada kontrol hanya dengan menyemprotkan aqua pro injection saja pada larva. Selanjutnya diamati setiap hari jumlah larva yang mati.

\section{Parameter Pengamatan}

Persentase mortalitas

Pengamatan mortalitas larva mulai dilakukan satu hari setelah aplikasi hingga 14 Hari Setelah Aplikasi (HSA). Persentase mortalitas dihitung dengan rumus:

$P=\frac{a}{b} \times 100 \% \ldots$ Pers
Dimana:

$\mathrm{P}=$ Persentase mortalitas kumbang tanduk (\%)

$\mathrm{a}=$ Jumlah kumbang tanduk yang mati

$\mathrm{b}=$ Jumlah kumbang tanduk yang diamati

\section{Kerapatan konidia jamur}

Jumlah kerapatan konidia jamur entomopatogen dihitung sebelum aplikasi dilakukan. Perhitungan kerapatan konidia dilakukan dengan cara suspensi masing-masing perlakuan dituang ke dalam tabung reaksi kecil, kemudian diambil $1 \mathrm{ml}$ dan dicampurkan dalam $9 \mathrm{ml}$ aqua pro injection. Kemudian divortex atau dishaker selama \pm 10 menit hingga suspensi homogen. Selanjutnya dilakukan pengenceran sebanyak 2 kali, lalu hitung konidia pada pengenceran $10^{2}$. Kemudian suspensi tersebut diambil sebanyak $0,1 \mathrm{ml}$ dan diteteskan pada haemocytometer lalu diamati di bawah mikroskop binokuler dengan perbesaran 400x dengan menggunakan rumus sebagai berikut:

$K=\frac{t x d}{(n \times 0,25) \times 10^{b}} \ldots \operatorname{Pers}$

Dimana:

K : Kerapatan konidia

$\mathrm{t}$ : Jumlah total konidia

d : Tingkat pengenceran

$\mathrm{n} \quad$ : Jumlah sampel yang diamati

0,25: Faktor koreksi penggunaan kotak sampel skala kecil pada haemocytometer.

Gejala kematian larva kumbang tanduk secara visual

Pengamatan gejala kematian larva kumbang tanduk yang terinfeksi jamur entomopatogen Metarhizium anisopliae dilakukan setiap hari setelah jamur diaplikasikan pada larva dan media. Pengamatan dilakukan dengan mengamati perubahan yang terjadi pada larva, yaitu berupa perubahan warna dari larva.

\section{Waktu kematian larva kumbang tanduk}

Waktu kematian larva kumbang tanduk diamati dari awal hingga benar-benar mati dan dicatat waktunya.

HASIL DAN PEMBAHASAN

Persentase Mortalitas Larva Kumbang Tanduk

Untuk menganalisis pengaruh pengaplikasian jamur Metarhizium anisopliae terhadap persentase mortalitas larva kumbang tanduk, 
telah dilakukan pengolahan data secara statistik, seperti disajikan pada Tabel 1 .

Berdasarkan Tabel 1 dapat dilihat, bahwa pengamatan pada 1-5 hari setelah aplikasi (HSA) jamur Metarhizium anisopliae menghasilkan persentase mortalitas tidak berbeda nyata terhadap seluruh perlakuan. Persentase mortalitas pengamatan pada 1-5 HSA tertinggi adalah pada perlakuan $\mathrm{M}_{2}$ (4-16\%). Sedangkan persentase terendah terdapat pada perlakuan $\mathrm{M}_{0}$ $(0 \%)$.

Selanjutnya pengamatan pada 6 HSA persentase mortalitas tertinggi adalah pada perlakuan $\mathrm{M}_{3}$ (40\%), sedangkan persentase terendah pada perlakuan $\mathrm{M}_{0}(0 \%)$. Pengamatan pada $6 \mathrm{HSA}$, terlihat bahwa perlakuan $\mathrm{M}_{3}$ berbeda tidak nyata dengan perlakuan $\mathrm{M}_{2}$ dan $\mathrm{M}_{1}$ tetapi berbeda nyata dengan perlakuan $\mathrm{M}_{0}$

Tabel 1. Rata-Rata Persentase Mortalitas Larva Kumbang Tanduk Akibat Pengaplikasian Jamur Metarhizium anisopliae

\begin{tabular}{ccccccccccccccc}
\hline \multicolumn{110}{c}{ Hari Pengamatan ke \% (HSA) } \\
\hline $\begin{array}{c}\text { Perlak } \\
\text { uan }\end{array}$ & $\mathbf{1}$ & $\mathbf{2}$ & $\mathbf{3}$ & $\mathbf{4}$ & $\mathbf{5}$ & $\mathbf{6}$ & $\mathbf{7}$ & $\mathbf{8}$ & $\mathbf{9}$ & $\mathbf{1 0}$ & $\mathbf{1 1}$ & $\mathbf{1 2}$ & $\mathbf{1 3}$ & $\mathbf{1 4}$ \\
\hline Mo & 0 & 0 & 0 & 0 & 0 & $0 \mathrm{~b}$ & ocC & $4 \mathrm{bB}$ & $8 \mathrm{bB}$ & $8 \mathrm{bB}$ & $20 \mathrm{bB}$ & $24 \mathrm{cC}$ & $24 \mathrm{bB}$ & $24 \mathrm{bB}$ \\
M1 & 0 & 0 & 0 & 4 & 8 & $24 \mathrm{a}$ & $48 \mathrm{bB}$ & $80 \mathrm{aA}$ & $88 \mathrm{a}$ & $92 \mathrm{aA}$ & $96 \mathrm{aA}$ & $96 \mathrm{bB}$ & $100 \mathrm{aA}$ & $100 \mathrm{aA}$ \\
$\mathrm{M} 2$ & 0 & 4 & 4 & 8 & 16 & $24 \mathrm{a}$ & $68 \mathrm{aA}$ & $92 \mathrm{aA}$ & $96 \mathrm{aA}$ & $100 \mathrm{aA}$ & $100 \mathrm{aA}$ & $100 \mathrm{aA}$ & $100 \mathrm{aA}$ & $100 \mathrm{aA}$ \\
$\mathrm{M} 3$ & 0 & 4 & 4 & 4 & 8 & $40 \mathrm{a}$ & $72 \mathrm{aA}$ & $92 \mathrm{aA}$ & $96 \mathrm{aA}$ & $100 \mathrm{aA}$ & $100 \mathrm{aA}$ & $100 \mathrm{aA}$ & $100 \mathrm{aA}$ & $100 \mathrm{aA}$ \\
\hline Keterangan : Angka yang diikuti huruf tidak sama besar dan kecil pada kolom yang sama menunjukkan berbeda nyata \\
pada taraf 5\% dan sangat nyata pada taraf 1\% menurut uji DMRT
\end{tabular}

Pengamatan pada 7 HSA persentase mortalitas tertinggi terdapat pada perlakuan $\mathrm{M}_{3}$ yaitu sebesar $(72 \%)$. Sedangkan persentase terendah terdapat pada perlakuan $\mathrm{M}_{0}(0 \%)$. Perlakuan $\mathrm{M}_{3}$ berbeda tidak nyata dengan perlakuan $\mathrm{M}_{2}$, tetapi berbeda sangat nyata dengan perlakuan $\mathrm{M}_{1}$ dan $\mathrm{M}_{0}$.

Pada pengamatan 8 HSA persentase mortalitas tertinggi terdapat pada perlakuan $\mathrm{M}_{3}$ dan $M_{2}(92 \%)$. Sedangkan persentase terendah terdapat pada perlakuan $\mathrm{M}_{0}(4 \%)$. Perlakuan $\mathrm{M}_{3}$ berbeda tidak nyata terhadap $\mathrm{M}_{2}$ dan $\mathrm{M}_{1}$, tetapi berbeda sangat nyata pada perlakuan $\mathrm{M}_{0}$.

Pengamatan pada 9 HSA persentase mortalitas tertinggi terdapat pada $\mathrm{M}_{3}$ dan $\mathrm{M}_{2}$ (96\%). Sedangkan persentase terendah terdapat pada perlakuan $\mathrm{M}_{0}(8 \%)$. Perlakuan $\mathrm{M}_{3}$ berbeda tidak nyata teradap $\mathrm{M}_{2}$ dan $\mathrm{M}_{1}$, tetapi berbeda sangat nyata pada perlakuan $\mathrm{M}_{0}$.

Pengamatan pada 10 HSA persentase mortalitas tertinggi terdapat pada $\mathrm{M}_{2}$ dan $\mathrm{M}_{3}$ $(100 \%)$. Sedangkan persentase terendah terdapat pada perlakuan $\mathrm{M}_{0}(8 \%)$. Perlakuan $\mathrm{M}_{3}$ berbeda tidak nyata teradap $M_{2}$ dan $M_{1}$, tetapi berbeda sangat nyata pada perlakuan $\mathrm{M}_{0}$.

Setelah pengamatan pada $10-14$ HSA, pada perlakuan $\mathrm{M}_{2}$ dan $\mathrm{M}_{3}$ larva sudah mati seratus persen (semua larva sudah mati). Sedangkan untuk perlakuan $\mathrm{M}_{1}$, kematian larva tercapai setelah 13 HSA. Sementara untuk perlakuan $\mathrm{M}_{0}$, persentase mortalitas larva stagnan pada 12 - 14 HSA sebesar $24 \%$. Artinya ada sebanyak $76 \%$ larva yang masih hidup hingga 14 HSA.

Untuk lebih jelasnya mortalitas larva Oryctes rhinoceros dapat dilihat pada Gambar 1. Pada Gambar 1, dapat dilihat bahwa pada perlakuan $\mathrm{M}_{1}, \mathrm{M}_{2}$ dan $\mathrm{M}_{3}$ terjadi kematian larva sebesar $100 \%$ atau semua larva mati. Pada perlakuan $\mathrm{M}_{2}$ dan $\mathrm{M}_{3}$, kondisi kematian larva $100 \%$ tercapai pada $10 \mathrm{HSA}$, sedangkan pada perlakuan $\mathrm{M}_{1}$ tercapai pada 13 HSA. Untuk perlakuan $\mathrm{M}_{0}$, persentase kematian larva hanya 24\% hingga 14 HSA. Kematian larva pada perlakuan $\mathrm{M}_{0}$ dapat disebabkan oleh karena larva tidak dapat untuk menyesuaikan diri dengan keadaan yang baru.

\section{Kerapatan Konidia}

Dari analisis secara statistik maka dapat diketahui bahwa kerapatan konidia jamur dengan pengenceran $10^{2}$ menunjukkan perbedaan pada setiap konsentrasi, seperti disajikan pada Tabel 2.

Dari Tabel 2 menunjukkan bahwa kerapatan konidia jamur Metarhizium anispliae tertinggi adalah pada konsentrasi 60 gr $\times 100^{-1}$ aqua pro

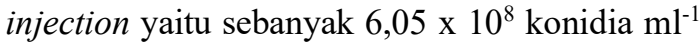
dan jumlah konidia terendah pada konsentrasi 20 gr $\mathrm{x} 100^{-1}$ aqua pro injection yaitu sebanyak 2,75 x $10^{8}$ konidia $\mathrm{ml}^{-1}$. 


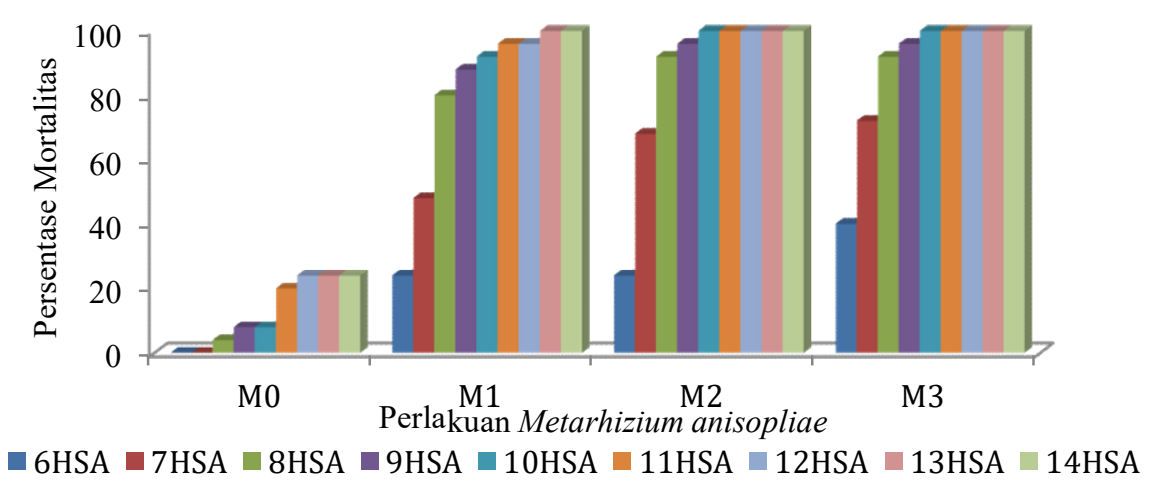

Gambar 1. Pengamatan Persentase Mortalitas Larva Kumbang Tanduk pada Jamur Metarhizium anisopliae

Tabel 2. Kerapatan konidia Metarhizium Anisopliae Dengan Berbagai Konsentrasi Per ml Aqua Pro Injection

\begin{tabular}{|c|c|c|}
\hline Jamur & Konsentrasi & 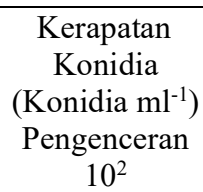 \\
\hline \multirow{3}{*}{$\begin{array}{c}\text { Metarhizium } \\
\text { anisopliae }\end{array}$} & $\begin{array}{c}20 \mathrm{gr} \times 100^{-1} \\
\mathrm{ml}\end{array}$ & $2,75 \times 10^{8}$ \\
\hline & $\begin{array}{c}40 \mathrm{gr} \mathrm{x} 100^{-1} \\
\mathrm{ml}\end{array}$ & $4,80 \times 10^{8}$ \\
\hline & $\begin{array}{c}60 \mathrm{gr} \times 100^{-1} \\
\mathrm{ml}\end{array}$ & $6,05 \times 10^{8}$ \\
\hline
\end{tabular}

\section{Gejala Kematian Larva Oryctes rhinoceros Secara Visual}

Dari hasil pengamatan yang dilakukan jamur Metarhizium anisopliae menyebabkan larva kumbang tanduk mati dan terinfeksi. Gejala kematian larva kumbang tanduk baik secara fisik maupun perilaku terjadi pada 2 hari setelah aplikasi. Dari hasil pengamatan larva kumbang tanduk yang terinfeksi awalnya masih aktif. Ketika laju infeksi mulai meningkat, pergerakan larva mulai melambat, nafsu makan berkurang, warna hijau pucat, terjadi paralisis secara total dan lama kelamaan menjadi diam dan mati, hal ini diikuti dengan mengerasnya dan mengeringnya tubuh larva, kutikula berwarna pucat merata pada seluruh tubuh dan larva uji akan mati dengan keadaan posterior mengecil. Ciri-ciri perubahan bentuk dan warna pada larva kumbang tanduk yang mati akibat terinfeksi jamur Metarhizium anisopliae dapat dilihat pada gambar 10 dan Gambar 2.

\section{Waktu Kematian Larva Kumbang Tanduk}

Data pengamatan waktu kematian larva Kumbang tanduk akibat aplikasi jamur entomopatogen Metarhizium anisoliae dapat dilihat pada Tabel 3 .

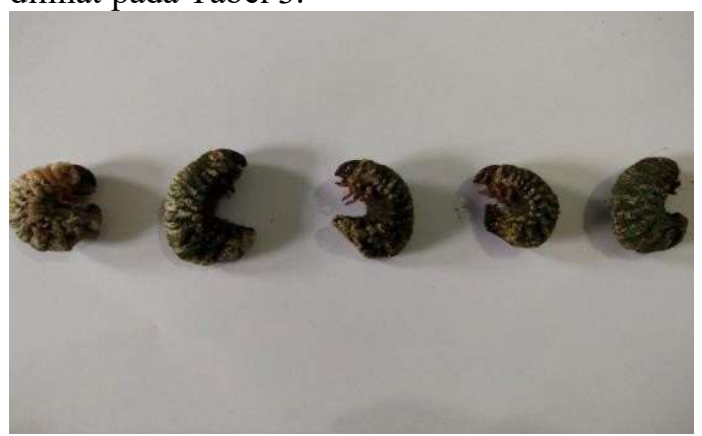

Gambar 2. Larva Kumbang Tanduk Yang Terinfeksi Metarhizium anisopliae

Tabel 3. Data Pengamatan Waktu Kematian Larva Kumbang Tanduk

\begin{tabular}{cc}
\hline Perlakuan & Waktu Kematian Larva (HSA) \\
\hline $\mathrm{M}_{0}$ & 8 \\
$\mathrm{M}_{1}$ & 4 \\
$\mathrm{M}_{2}$ & 2 \\
$\mathrm{M}_{3}$ & 2 \\
\hline
\end{tabular}

Dari Tabel 3 dapat diketahui bahwa waktu yang dibutuhkan jamur Metarhizium anisopliae untuk menyebabkan kematian awal adalah 2 HSA pada perlakuan $\mathrm{M}_{2}$ dan $\mathrm{M}_{3}$. Dan 4 
HSA pada perlakuan $\mathrm{M}_{1}$. Selanjutnya kematian 8 HSA pada perlakuan $\mathrm{M}_{0}$.

Aplikasi jamur entomopatogen Metarhizium anisopliae dengan perlakuan $\mathrm{M}_{2}$ dan $\mathrm{M}_{3}$ lebih cepat mematikan larva kumbang tanduk yaitu selama 2 hari. Hal ini karena pada perlakuan $\mathrm{M}_{2}$ dan $\mathrm{M}_{3}$ memiliki konsentrasi yang tinggi. Semakin tinggi konsentrasi yang diberikan maka semakin banyak pula konidia yang kontak dengan tubuh larva. Sehinga semakin banyak konidia yang berkecambah dan melakukan penetrasi ke dalam tubuh larva.

Ketika terjadi kontak antara konidia cendawan dengan kutikula serangga yang peka, konidia tersebut akan berkembang dan masuk sampai bagian dalam dari tubuh serangga tersebut. Pada saat jamur Metarhizium anisopliae berada dalam tubuh larva, cendawan akan mengeluarkan toksin yang dapat merusak jaringan yang terinfeksi secara menyeluruh sehingga dapat mengakibatkan kematian pada serangga.

Berdasarkan hasil penelitian dapat dijelaskan dengan pemberian jamur entomopatogen Metarhizium anisopliae pada pengamatan 1-14 HSA dapat dilihat bahwa pada setiap perlakuan mengalami peningkatan mortalitas setiap hari. Hal ini karena jamur membutuhkan waktu untuk melakukan infeksi dan berkembang di dalam tubuh larva dengan menyerap cairan tubuh larva dan mengakibatkan semakin banyak larva yang mati setiap hari. Larva yang masih bertahan lama kelamaan akan melemah hingga mengalami kematian.

Terjadinya fluktuasi mortalitas harian untuk setiap perlakuan hal ini karena konsentrasi jamur Metarhizium anisopliae yang diaplikasikan berbeda-beda sehingga tingkat virulensinya juga berbeda. Pada pengamatan 1-5 HSA berpengaruh tidak nyata terhadap persentase mortalitas larva. Rendahnya mortalitas dikarenakan cara kerja jamur Metarhizium anisopliae yang bersifat sistemik dan membutuhkan waktu untuk melakukan infeksi dan berkembang di dalam tubuh larva dengan menyerap cairan tubuh larva kemudian mengakibatkan kematian pada larva [8].

Jamur entomopatogen Metarhizium anisopliae bersifat spesifik inang. Maksudnya jamur tersebut akan lebih efektif dalam mengendalikan hama jika hama itu adalah inang sasarannya. Menurut [9] jamur Metarhizium anisopliae spesifik inang terhadap hama dari ordo coleoptera terutama kumbang tanduk. Pada
6 HSA persentase mortalitas berpengaruh nyata terhadap larva dan pada pengamatan 7-14 HSA berpengaruh sangat nyata terhadap persentase mortalitas larva.

Hasil pengamatan menunjukkan bahwa jamur Metarhizium anisopliae, efektif dalam mengendalikan larva kumbang tanduk. Hal ini sesuai dengan pernyataan [10], bahwa cendawan entomopatogen dapat dikatakan efektif apabila agens tersebut mampu menyebabkan kematian serangga uji mencapai $60-100 \%$. Pada pengamatan $10 \mathrm{HSA}$ persentase mortalitas sudah mencapai (100\%). Hal ini menunjukkan bahwa pada 10 HSA konidia jamur Metarhizium anisopliae yang masuk melakukan infeksi dalam tubuh larva Kumbang Tanduk sudah menunjukkan aktivitas yang sangat baik, karena bila ditinjau dari mulai jamur masuk ke dalam tubuh larva sampai menunjukkan gejala kematian paling lama 10 hari.

Dari hasil pengamatan menunjukkan bahwa semua perlakuan jamur Metarhizium anisopliae mampu membunuh serangga uji larva kumbang tanduk. Kematian larva disebabkan oleh jamur Metarhizium anisopliae yang mampu menghasilkan toksin yang mengakibatkan gangguan fungsi hemolimfa, terganggunya sistem pencernaan, gangguan inti sel serangga inang, dan hilang kesadaran serta kerusakan jaringan tubuh menyeluruh dalam tubuh larva. Sesuai dengan pernyataan [11] pertumbuhan spora dalam tubuh larva akan mengganggu seluruh aktivitas organ dan berakibat kematian pada larva.

Perlakuan yang paling efektif dalam mengendalikan larva adalah M2 dan M3 dengan persentase mortalitas sebesar $100 \%$ telah tercapai pada 10 HSA. Tingginya mortalitas larva pada perlakuan ini disebabkan konidia yang diaplikasikan langsung ke tubuh larva dapat segera masuk atau melakukan infeksi pada tubuh larva sehinga mempercepat proses kematian larva. Selain itu jumlah konidia yang diaplikasikan juga tinggi. Hal ini sesuai dengan yang dinyatakan [12] dan [13] bahwa semakin tinggi jumlah konidia yang diaplikasikan maka konidia yang menempel pada tubuh larva akan semakin banyak sehingga mempercepat kematian larva.

Pada perlakuan $\mathrm{M}_{0}$ juga terjadi mortalias larva, hal ini karena larva tidak dapat untuk menyesuaikan diri dengan keadaan yang baru. Hal ini sesuai dengan yang dinyatakan [6], bahwa serangga uji yang tidak mampu 
beradaptasi dengan lingkungan yang baru akan mati sedangkan yang mampu beradaptasi akan bertahan hidup. Konsentrasi konidia dalam biakkan Metarhizium anisopliae yang baik adalah mengandung 500 juta $\left(5 \times 10^{8}\right)$ konidia atau lebih dalam setiap gram.

Menurut [14], hasil pengamatan mortalitas larva Kumbang Tanduk akibat infeksi jamur M. anisopliae dengan kerapatan spora $10^{7}$ konidium per $\mathrm{ml}$ belum mampu menyebabkan mortalitas larva instar III kumbang tanduk.

Jamur Metarhizium anisopliae yang dibiakkan pada media beras memiliki kerapatan konidia dan viabilitas konidia yang tinggi, hal ini disebabkan karena kandungan gizi, seperti karbohidrat (sekitar $80-85 \%$ ), protein, vitamin dan mineral yang dapat digunakan oleh jamur Metarhizium anisopliae untuk tumbuh dan berkecambah [2]. Tinggi rendahnya kerapatan konidia jamur selain ditentukan oleh faktor genetik juga dipengaruhi faktor luar, antara lain suhu, $\mathrm{pH}$, dan lamanya masa inkubasi. Suhu dan $\mathrm{pH}$ yang ideal untuk perbanyakan kondia $M$. anisopliae adalah $25-30^{\circ} \mathrm{C}$ dan $\mathrm{pH} 7$ [15].

Pembentukan konidia jamur dipengaruhi oleh kandungan protein dalam media. Jamur entomopatogen membutuhkan oksigen, air dan sumber organik karbon dan energi. Sumber nitrogen organik maupun anorganik dan bahan tambahan lainnya berupa mineral maupun pemacu tumbuh juga diperlukan. Sumber karbon yang digunakan sebagai media adalah dektrosa namun dapat diganti dengan polisakarida seperti tajin atau lipid.

Nitrogen dalam bentuk nitrat, ammonia atau bahan organik seperti asam amino atau protein. Makronutrisi penting yang lain adalah phosphor (dalam bentuk phospat), potassium, magnesium dan sulfur (yang disediakan dalam bentuk sulfat maupun dalam bentuk organik, cystein atau methionine). Mikronutrisi penting yang dibutuhkan oleh jamur entomopatogen adalah kalsium, besi, tembaga, mangan, molybdenum, zink dan vitamin B komplek, khususnya biothine dan thiamine. Semua mikronutrisi ini biasanya terdapat dalam bahan mentah, akan tetapi dapat dipenuhi dalam bentuk protein hidrolisat atau ekstrak yeast [16].

Konidia Metarhizium anisopliae akan berkecambah pada kutikula inang ketika menginfeksi serangga, melakukan penetrasi dengan senyawa hidrolisis (peptidase dan kitinase), lalu dengan bantuan tekanan mekanis, enzim tersebut menghancurkan kulit dengan cara lisis. Enam enzim yang dihasilkan oleh jamur $M$. anisopliae, diantaranya enzim lipase, kithinase, amylase, proteinase, pospatase, dan esterase [17]. Setelah jamur masuk, konidianya dengan cepat memperbanyak diri sehingga blatospora segera meliputi tubuh inang.

Kematian inang disebabkan oleh kolonisasi miselia yang ekstensif sehingga menyebabkan starvasi atau melalui racun yang dilepaskan pada saat penyerangan. Desifikasi cadaver digunakan sebagai nutrisi dan air oleh hifa. Hifa memecah kutikula setelah serangga mati. Konidia bebas berkembang meneruskan siklus infeksi [7]. Semakin banyak konidia yang melakukan penetrasi menyebabkan semakin banyak enzim dan toksin yang dikeluarkan oleh cendawan.

Dengan demikian, pada kondisi formulasi cair jamur entomopatogen membunuh dengan dua lini, yaitu lini pertama karena pertumbuhan spora jamur, sedangkan pada lini kedua adalah mikotoksin yang ada dalam formulasi. Menurut [9] dan [1] mekanisme infeksi Metarhizium anisopliae dapat digolongkan menjadi empat tahapan etiologi penyakit serangga yang disebabkan oleh jamur.

Tahap pertama adalah inokulasi, yaitu kontak antara propagul jamur dengan tubuh serangga. Tahap kedua adalah proses penempelan dan perkecambahan propagul jamur pada integument serangga. Tahap ketiga yaitu penetrasi dan invasi, yaitu menembus integument dapat membentuk tabung kecambah (appresorium). Tahap keempat yaitu destruksi pada titik penetrasi dan terbentuknya blatspora yang kemudian beredar ke dalam hemolimfa dan membentuk hifa sekunder untuk menyerang jaringan lainnya.

Kontak antara larva yang telah terinfeksi dengan larva yang masih sehat akan membuat jamur menempel pada tubuh larva lainnya. Penularan konidia dari larva yang terinfeksi kepada larva yang sehat disebabkan adanya interaksi antar individu, seperti tingkah laku larva yang saling menyuapi (trophallaxis) dan saling bersentuhan (grooming) [1]. Sebagai serangga sosial tingkah laku larva selalu berhubungan dengan anggota yang lain dalam koloninya.

Berdasarkan pengamatan yang dilakukan, terlihat bahwa larva yang mati akibat aplikasi jamur entomopatogen Metarhizium anisopliae ini akan berada pada bagian atas media makan larva. Hal ini termasuk salah satu ciri sesuai dengan larva yang mati akibat pengaplikasian 
jamur entomopatogen. Setelah larva mati tubuh larva kaku dan muncul hifa berwarna putih pada hari ke 2 setelah mati, terutama pada bagian anterior dan posterior. Pada hari ketiga setelah mati, cendawan berporulasi warna hijau.

Tubuh larva yang telah mati tertutup cendawan berwarna hijau pada hari ke 5-10 setelah mati. Pada awal infeksi mulai muncul hifa jamur Metarhizium anisopliae berwarna putih dan akhirnya seluruh tubuh larva akan ditumbuhi hifa berwarna hijau. Selain mengeras tubuh larva juga berubah menjadi hitam. Perubahan warna hitam yang terjadi pada tubuh larva disebabkan oleh melanisasi yang merupakan suatu bentuk pertahanan tubuh serangga untuk melawan patogen [1].

Perubahan warna hitam atau melanisasi tersebut akibat dari aktifitas enzim phenoloksidase. Enzim ini diketahui berperan dalam proses penyembuhan luka, sklerotisasi kutikula. Hasil pengamatan menunjukkan bahwa mortalitas lebih cepat dari pada munculnya koloni jamur pada larva. Hal ini diakibatkan karena jamur memerlukan waktu yang lebih lama untuk memunculkan hifanya disekitar tubuh inang karena harus melalui tahapan infeksi.

Setelah serangga mati, jamur akan terus melanjutkan siklus hidup dengan membentuk koloni di sekitar tubuh inang. Semua jaringan dalam tubuh serangga dan cairan tubuh habis digunakan oleh jamur, sehingga serangga akan mati dengan tubuh mengeras seperti mumi, hal ini dikarenakan larva diselimuti oleh miselium jamur [1].

\section{Kesimpulan}

\section{KESIMPULAN DAN SARAN} bahwa:

Dari hasil penelitian dapat disimpulkan

a. Persentase mortalitas larva kumbang tanduk sebesar $100 \%$ dapat tercapai pada perlakuan $\mathrm{M}_{1}, \mathrm{M}_{2}$ dan $\mathrm{M}_{3}$, sedangkan pada perlakuan $\mathrm{M}_{0}$ hanya $24 \%$

b. Waktu yang dibutuhkan jamur Metarhizium anisopliae untuk menyebabkan kematian larva $100 \%$ pada perlakuan $\mathrm{M}_{2}$ dan $\mathrm{M}_{3}$, adalah 10 HSA dan perlakuan $\mathrm{M}_{0}$ adalah pada 13 HSA. Sementara perlakuan $\mathrm{M}_{0}$ hanya menyebabkan kematian sebanyak $24 \%$.

\section{Saran}

Perlu dilakukan penelitian lebih lanjut mengenai cara aplikasi jamur Metarhizium

DOI: https://doi.org/10.55127/ae.v15i2.101 anisopliae terhadap larva kumbang tanduk langsung di pertanaman kelapa sawit.

\section{DAFTAR PUSTAKA}

[1] Khairunnisa, S, Pinem, MI dan Zahara, F. 2014. Uji Efektifitas Nematoda Entomopatogen sebagai Pengendali Penggerek Pucuk Kelapa Sawit (Oryctes rhinoceros L.) (Coleoptera: Scarabaidae) Di Laboratorium. Agroekoteknologi. 2 (2): 607-620.

[2] Manurung, EM, Tobing, MC, Lubis, L, Priwiratama, H. 2012. Efikasi Beberapa Formulasi Metarhizium anisopliae Terhadap Larva Oryctes rhinoceros L. (Coleoptera: Scarabaeidae) di Insektarium. Agroekoteknologi. 1 (1).

[3] Salbiah, D., Laoh, J.H., dan Nurmayani. 2013. Uji Beberapa Dosis Beauveria bassiana vuillemin terhadap Larva Hama Kumbang Tanduk Oryctes rhinoceros (Coleoptera: Scarabaeidae) Pada Kelapa Sawit. Jurnal Ilmiah Sains Terapan. 4 (2): 137-142.

[4] Fauzana, H, Sutikno, A, Salbiah, D. 2018. Population Fluctuation of Oryctes rhinoceros L. Beetle in Plant Oil Palm (Elaeis guineensis jacq.) Given.

[5] Nuriyanti, DD, Widhiono, I, Suyanto, A. 2016. Faktor- Faktor Ekologis Yang Berpengaruh Terhadap Struktur Populasi Kumbang Badak (Oryctes rhinoceros L.). Biosfera. 33(1)

[6] Nasution, L, Bakti, D. 2018. Identification of Fungi Originated From Soil Polluted by Dichloro Diphenil Trichloroethane (DDT). International Conference on Agribussines, Food and Agro-Technology. Sci.205012021. Doi:10.1088/1755-315/205/1/012021.

[7] Sihombing, RH, Oemry, S, Lubis, L. 2014. Uji Efektifitas beberapa Entomopatogen Pada Larva Oryctes Rhinoceros L. (Coleoptera:Scaraebidae) di Laboratorium. Agroekoteknologi. 2 (4): 1300-1309.

[8] Nasution, L, Anggraeni, N, Siregar, AZ Nuraida. 2017. Patogenicity Aspergillus sp And Metarhizium 
anisopliae On Larva Of Oryctes rhinoceros On Palm Oil Plant (Elaeis guineensis Jacq) In Vitro. International Journal of Trend In Research And Develovment. 4(4)

[9] Marheni, Hasanuddin, Pinde dan Suziani, W. 2012. Patogenisitas Metarhizium anisopliae dan C. militalis Terhadap Penggerek Pucuk Kelapa Sawit. Agroteknologi. 32 (39)

[10] Ou, SH. 1972. Rice Disease. Plant Phathology. The International Rice Institute. Los Banos, Philippines: p. 45

[11] Nunilahwati, H. 2012. Eksplorasi Isolasi dan Seleksi Jamur Entomopatogen Plutella xylostella (Lepidoptera : Yponomeutidae) Pada Pertanaman Caisin (Brassica chinensis) di Sumatera Selatan. Jurnal HPT Tropika. 12 (9)

[12] Erixon M, H., Oemry, Syahrial dan Zahra, F. 2015. Uji Efektifitas Suspensi Baculovirus oryctes dan Metarhizium anisopliae (Metch) Sorokin Terhadap Brontispa longissima Gestro. (Coleoptera: Chrysomelidae) di Laboratorium. Agroteknologi. 3 (1): 124-128

[13] Mardiana, Y, Salbiah, D, Laoh, H. 2015. Penggunaan Beberapa Konsentrasi Beauveria bassiana Vuillemin Lokal Untuk Mengendalikan Maruca testulatis Geyer pada tanaman Kacang Panjang (Vigna sinensis L.). JOM Faperta. 2(1): 22-32.

[14] Bintang, AS, Wibowo, A, Harjaka, T. 2015. Genetic Diversity of Metarhizium anisopliae And Virulence toward Larvae Of Rhinoceros Beetle (Oryctes rhinoceros). Jurnal Perlindungan tanaman Indonesia. 19 (1): 12-18

[15] Thalib, R, Fernando, R, Khodijah., Meidalima, D, Herlinda, S. 2013. Patogenisitas Isolat Beauveria bassiana dan Metarhizium anisopliae Asal Tanah Lebak dan Pasang Surut Sumatera Selatan Untuk Agens Hayati Scirpophaga incertulas. Jurnal Hama dan Penyakit Tanaman Tropika. 13 (1):10-18

[16] Humairoh, D, Hidayat, MT, Prayogo, Y. 2013. Pengaruh Kombinasi Jenis Jamur Entomopatogen Dengan Kerapatan Konidia Terhadap Intensitas Serangan Ulat Grayak. Lentera Berkala Ilmiah Biologi. 2(1): 19-23

[17] Ulya, LN., Himawan, T, Mudjiono, G. 2016. Uji Patogenisitas Jamur Entomopatogen Metarhizium anisopliae (Moniliales: Moniliaceae) Terhadap Hama Uret Lepidiota stigma 